\title{
HUMANIZED COLLECTIVE AWARENESS IN ISLAMIC EDUCATION FOR PUBLIC PROSPERITY: \\ A CROSS-CULTURAL AND RELIGIOUS PSYCHOLOGICAL STUDY
}

\author{
${ }^{1}$ Kana Safrina Rouzi, ${ }^{2}$ Fitriah M. Suud, ${ }^{3}$ Moh. Toriqul Chaer \\ 1Universitas Alma Ata Yogyakarta \\ 2Universitas Muhammadiyah Yogyakarta \\ 3STAI Masjid SyuhadaYogyakarta \\ toriqul210874@gmail.com
}

\section{ABSTRACT}

Islamic education is essential even as the spearhead for the development of religion, culture, and humanity because the aim of Islamic education, in general, is to be rahmatan lil alamin, which means non-discrimination through understanding the meaning of Al-Hujurât: 13. This meaning exists in the offer of teaching solutions with an interfaith and cultural approach with a reflective method. It produces self-awareness that is Islamic education requiring not only teaching religion is essential, but also how to explore and understand more substantive religious values so that one day can become a more spiritual and humanist human being. The purpose of this research is to present text studies as a solution to the current cultural and religious diversity. The result found that collective awareness in the frame of religiosity needs to be in Islamic education for the benefit of the people in a country with a high level of diversity.

Keywords: Collective Awareness, Islamic Education, Religion, CrossCultural Psychology, Interfaith Psychology

\section{ABSTRAK}

Pendidikan Islam sangat penting bahkan sebagai ujung tombak bagi 
perkembangan agama, budaya, dan kemanusiaan karena tujuan pendidikan Islam, secara umum, adalah menjadi rahmatan lil alamin, yang berarti non-diskriminasi melalui pemahaman makna Al-Hujurât: 13. Makna ini ada dalam tawaran solusi pengajaran dengan pendekatan antaragama dan budaya dengan metode reflektif. Ini menghasilkan kesadaran diri yaitu pendidikan Islam yang membutuhkan tidak hanya mengajar agama sangat penting, tetapi juga bagaimana mengeksplorasi dan memahami nilai-nilai agama yang lebih substantif sehingga suatu hari dapat menjadi manusia yang lebih spiritual dan humanis. Tujuan penelitian ini adalah untuk menyajikan studi teks sebagai solusi untuk keragaman budaya dan agama saat ini. Haasil penelitian menemukan bahwa kesadaran kolektif dalam bingkai religiusitas perlu dalam pendidikan Islam untuk kepentingan umat di negara dengan tingkat keragaman yang tinggi.

Kata Kunci: Kesadaran Kolektif, Pendidikan Islam, Agama, Psikologi Lintas Budaya, Psikologi Antar Agama

\section{INTRODUCTION}

Islam, as the religion of rahmatan lil'âlamîn, teaches concern for fellow human beings far more critical than rituals to God. The loyalty of a Muslim appears if he defends his fellow humans who need it. Helping others is a way to get closer to God because whoever knows himself and others knows his God. Islam teaches that loyalty only happens if it gives what is best for itself. Only a believer can do that because of his belief that God will help those who help others. In a social life that is continuously changing and developing, Islam is a universal religion intended for the universe, not only for Muslims. Thus, it is essential to measure loyalty and devotion not only from standard rituals but also from humanitarian commitments because that is the purpose of life in this world to be able to live peacefully along with various religions, ethnic groups, and multiple understandings.

As a religion of peace, people can understand better Islam through education. Education is a demand for the democratization and development of civilization as well as science and technology with a design and a system expected to grow in a format to make students independent, critical, and creative. It becomes increasingly strategic, considering Islam is an alternative educational paradigm loaded with values in analyzing issues related to the symptoms of education. This article tries to give an argument about the importance of Islamic education as the spearhead for the development of religion, culture, and humanity. Also, the author attempts to offer a solution 
to the concept of teaching inter-religious and cultural psychology through the factors of Islamic maturity and education in the realities of life.

\section{METHODS}

This study uses a hermeneutic Fazlur Rahman's which is Double Movement Interpretation. A new approach that emphasizes the awareness of text, context, and contextualization. The historical characteristic of the Qur'an has led to the emergence of hermeneutic ideas and theories (the method of interpretation).

This method provides a systematic and contextualist understanding, resulting in an interpretation that is not atomistic, literal and textual as well as an interpretation that is able to answer contemporary problems. As for what is meant by a double movement is: starting from the present state until the time when the Qur'an was revealed and returned to the present.

Rahman's double movement consists of two stages. The first stage consists of two steps, first, understanding the meaning of a statement by examining a historical situation or problem so as to produce an understanding of the meaning of the Qur'an as the answer. The second step is to generalize specific answers in the Qur'an, and use them in the form of general statements about moral-social aims. The second stage is to formulate this general view into a concrete socio-historical context that is developing.

The role of the writer in this study is as a reader and receiver of meaning as well as a second meaning giver. The author examines carefully to get valid, objective and responsible data because the author acts as a planner, data collector, data analyzer and data interpreter as well as a research report maker. The data analysis in this study adopts Fazlur Rahman's hermeneutic theory to study specific matters in the Qur'an, then explore and systematize general principles, values and long-term goals. Furthermore, considering that the text has its own context, it is necessary to study the social-setting in which the text appears to interpret and understand the text. In the application stage, this theory does not use the literal meaning of the text but the moral ideal of the text.

The research steps in this paper adopted from the stages of Fazlur Rahman's Double Movement which consisted of: (Stage 1) Identify the understanding of the meaning of the Qur'anic text through asbabun nuzul and the opinions of the commentators. (Stage 2) Carefully determine the elements analyzed so that the situation can be assessed and changed as needed and set new priorities for applying values according to the present 
context based on the Qur'an. This is to determine the effective orientation and ethical engineering in the current concrete socio-historical context. This can get a solution from the concept of teaching psychology across religions and cultures through Islamic maturation and education in the realities of life. Therefore, the current situation needs to be studied to get an understanding and interpretation that will become the conceptual solution as shown below:
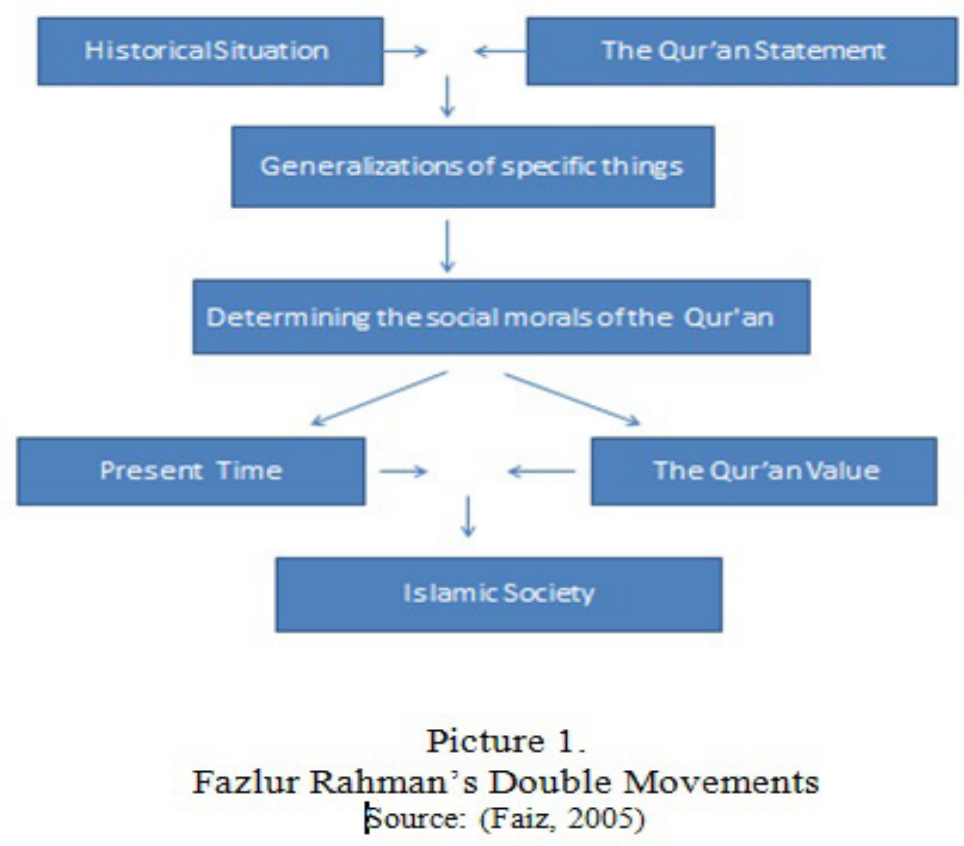

This research is a type of literature study research (text study) is research in which the study is carried out by examining and tracing various literatures. In research, this text study includes literature studies where all the substance requires theoretical processing related to values such as problems, concepts, methods and phenomena that is contained in the theories that this article studies.

A review of the academic literature assists to establish existing theories, the relationships between them, the stage of existing approaches, and the development of new studies to be inspected. In this theory, the approach used is interfaith and cultural psychology through the factor of maturity and Islamic education for human wellbeing. 


\section{RESULT AND DISCUSSION}

When the world is near destruction, when religion is more often associated with war than peace, and when confusion and doubt engulf the human psyche, Islamic education can remind that the best hope is to rest on its highest origin, its spirit because islamic education as the spearhead of the development of religion, culture, and humanity.

Education is necessary to understand the vision because humans then can understand what is wrong and right about preparation for the life of the world and the hereafter. The main idea of education in Islam and its ultimate goal is not to dominate nature and to gain power and external forces, but how to master oneself. According to Suhrawardi, education is inseparable from spiritual life. The Islamic education system never separates between mind and spirit education and all aspects of humanity.

Islamic education is an education based on Islamic teachings containing aqidah systems, value systems, and norms with rules, guidance, regulations, and information, and systems of forming ideas or concepts of thinking, belief, interaction, and culture, which is material and conceptual. Also, primary Islamic education is the Koran, al-Sunnah, ulama opinions, and historical heritage. In addition to considering analytical and empirical data, Islamic education has a base on the Koran, al-Sunnah, ulama opinions, and historical heritage. The purpose of Islamic education is in line with the objectives of Islamic teaching, which is to build a human life that is obedient and submissive to God and brings mercy to all of nature (Surah Al-A'raf: 73).

The word obedient and submissive to Allah in that verse has a comprehensive meaning, namely carrying out all the commands of Allah in all aspects of life, such as economic, social, political, cultural and so on based on the values of faith, devotion, hard work, justice and so on. The word grace can mean peace, appreciation, compassion, tolerance, honesty, humility, cooperation, or unity. The term of grace, according to al-Raghib al-Asfahani, is as follows. A gentle attitude requires treating loved ones well and sometimes also does not hope anything in return, as God has done affection for His followers.

Omar Muhammad Al-Toumy Al-Syaibani states that the aim of Islamic education has four characteristics. They are the nature of religion and character; comprehensive nature, which includes self and community development; the nature of the balance between and its elements; realistic and workable. Furthermore, in the formulation of the objectives of Islamic education, several issues need attention. They are, first, the goal as the direc- 
tion to achieve, in the form of the direction of children's development according to their level of development, needs, feelings, concerns, and environment and changes in behavior. Second is the interim goal and the final goal, which is ushering into the final destination, including the philosophy of life and education in Islam that is transcendent. The third is relative goals and absolute goals. Relative goals are goals that are easy to change because of the level of development, conditions, and situations. In contrast, absolute goals are goals formulated based on ideal values that contain universal truth and goodness.

According to Muhammad Fadhil Al-Jamaly the objectives of Islamic education, according to the Qur'an, include (1) explanations of students as servants of God who have responsibilities in this life; (2) a description of its relationship as a social creature that is responsible for the order of social life; (3) an explanation of man's relationship with nature and his duty to find out the wisdom of creation by prospering the universe; (4) a description of its relationship with God, who created the world. Thus, the goal of Islamic education is in line with the teachings of Islam based on the realization of compassion for all creatures created by God, who turned out to have an extensive range of understanding, namely compassion and love. This reality shows that the peace and tranquility blooming and coming from within every human being makes harmony in the world, reaches all aspects of life, and is useful.

\section{Textual Solutive Concept}

From a cultural perspective, education in the global era is an important vehicle and an effective medium for teaching norms, promoting values, and instilling ethos among Muslims. Islamic education can be an instrument to foster Muslim personalities, strengthen Muslim identity, and enhance Muslim identity. Even the role of Islamic education becomes more critical when the current of globalization is so strong that it influences the different values and cultures with the personality of Indonesia.

For this reason, if it is very urgent to avoid the young generation behaving not following the norms of society (Islam), culture and humanity are to restore the integrated teaching-learning process that links worldly concepts by surrender to Allah SWT. In this context, Islamic education can be a strategic vehicle to build collective conscience as a people and strengthen social ties, while respecting cultural, racial, ethnic, and religious diversity to enhance social harmony (Surah Al-Hujuraat: 13). The teachings of Islam are 
closely related to the issue of divinity and humanity both within the framework of science, morals, and comprehensive deeds in all human life. To offer solutions to the problems of the reality of life-related to Islamic education, it helps us to see and apply the principles of Islamic education.

The first principle of Islamic education is the primary right of children's education in the parents' hands while society and the country have secondary rights. Parents are obliged to educate their children to become a true Muslim (QS. Ali Imran: 85). Second, education must be equal between education in the hereafter and the world (QS. Al-Qashash: 77). Third, education should have a proper direction so that students become people who obey Allah (QS. Al-Araaf). Fourth, education should bring students into people with good character and love, so they want to compete in goodness (QS. Al-Mukminun: 61).

Another important thing is that Islamic education is for self-development (nafs) the essence of humanity. For this purpose, the teaching-learning process must equip students with religious, ethical, legal, historical, and Islamic civilization lessons without ignoring the technical subject matter. Teaching, as mentioned above, is expected to plant the seeds of faith in the hearts of students. This problem is not only the responsibility of teachers and schools but also the responsibility of parents and the community (people) to train this young generation in all aspects of Islamic teachings until they get self-maturity.

\section{Factors of Maturity in Crossing Religion and Culture in Adolescents}

Humans experience two kinds of development, namely physical and spiritual development. Chronological age measures physical development. The peak of physical development achieved by humans is called maturity. On the contrary, spiritual development is estimated based on the level of ability (ability). Reaching a certain level of competence for spiritual development is termed Maturity. The development itself is the changes experienced by individuals towards the level of maturity that takes place systematically, progressively, and continuously, namely:

a. Systematic means that changes in these developments are mutually influencing between parts of the organism (physical and psychological) and are a harmonious whole;

b. Progressive is advanced, increased, and profound changes, both quantitatively (physically) and qualitatively (psychologically); 
c. Continuous, i.e., changes do not happen irregularly, but there are regular stages.

In the division of development stages, adolescence occupies a progressive stage. At this stage, a period of physical and spiritual development affects one's appreciation of religious teachings characterized by several factors. They are, first, the growth of mind and mentality that causes adolescents to be critical of religious, cultural, social, and other forms of life. Second, the development of feelings such as social, ethical, and aesthetic feelings encourages adolescents to experience the influence of their environment, which leads to the situation created by that environment. Third, social considerations also give a religious style because they are confused about moral or material concerns. Fourth, moral development in adolescents starts from feeling guilty and attempts to seek protection.

Adolescents feel hesitant to determine between religious or mystical elements. An environment that sometimes unknowingly causes dilemmas in adolescents becomes the leading cause of the issue. Only the basis of knowledge gained through education will influence one's attitude towards religious teachings. Smart adolescents will become more critical so that so they can interpret spiritual teachings more rationally, understand or recognize the value of religion and make it noble values in attitude and behavior. Then, he has matured in faith. A person's religious maturity is visible from religious beliefs and behavior that reflect obedience to his religion.

Adolescence means spending a lot of time with peers, both at school and elsewhere. During this period, adolescents have confrontations with religious, cultural, and social influences. All problems in adolescents have connections with the age they pass and are inseparable from the control of the environment. In this case, an essential factor that plays a decisive role in the lives of adolescents is religion. However, the situation does not realize the impact of religion. Also, the culture lacks where the influence is critical and significant in human life, especially in people with mental turmoil, that is, at the age of adolescents, known as 'unstable age' because of growth and development through all fields and aspects of life. Besides, what also disturbs adolescents is the difference between the moral values taught by religion and the behavior of people in society-especially seen in parents, teachers in schools, leaders, and religious leaders. There are many more factors that shake the souls of adolescents. Religion teachers should be able to understand them, so that they can dive into their souls, then bring them to the 
knowledge and tame their rocky souls.

Those aspects must be present in the teaching of interfaith and cultural psychology in high schools, private and public institutions. Education, which includes understanding moral and cultural lessons, aims to reduce and eliminate the shock through attention to the experience and appreciation of the world in a person about divinity accompanied by faith and worship. And this must begin in adolescence, where the start of the formation and development of a personal moral system is in line with the growth of individual religious experiences. Through spiritual awareness and knowledge, adolescents will finally find their God, which means finding their personality. They will also find principles and norms regarding life, conscience, and the meaning and purpose of their life. Their diverse consciousness becomes subjective and independent autonomous so that their attitude and behavior are a reflection of the state of their inner world, the appearance of faith, and a steady personality.

\section{Solutive Offers in the Implications and Applications of Interfaith and Cultural Psychology}

Education is a conscious effort to make the learning process of students towards maturity (maturity). Learning is the delivery of knowledge or a series of activities to provide opportunities to develop themselves. Maturity will produce loyalty, which is later more popular with the term religion as a result of education when connected with efforts to teach religious values. The religious context in education is self-awareness for the growth of divine awareness. This aspect grows in the spectrum of individual consciousness as a whole, a balance between mental and physical development, belief and intellect, feelings and reason, and the world and hereafter. However, they are not limited to worship but must have a realization in a real charity with an attitude of social care attitude.

The learning model, as explained above, is reflective It combines the active learning model with the reflexive-dialogist learning model. This learning provides active learning by involving self-experience as learning material to help and shape students to think creatively based on their knowledge and experience. The involvement of these experiences must be in learning because education itself is a civilizing processand works as a tool for cultural change. This learning process is a process of formal acculturation, which is solely not only cultural transmission and adoption but also cultural change.

Reflective ability as a learning outcome has base on the concept of reflec- 
tive learning, where this learning provides an opportunity for students to do an analysis or experience and actualize the background in education. In practice, J Drost uses five steps in the reflective learning process. First is the context, efforts to foster religious education in the development of spiritual values by the way each child is valued, how he demonstrates his kindness, and appropriately and right. Second is experience, efforts to foster religious values by interaction and communication in the learning community while imagining, telling stories, playing roles, reading, or watching short stories. The third is the reflection, which is facilitating students with questions related to children's experiences and asking children to explore and believe in the values contained in the background.

Fourth is action, facilitating children with action questions, then reflecting in behavior so that they become a champion of the indicated values. The fifth is the evaluation. It is the stage after learning to see the realm of development and academics so that children can be competent in the social and academic fields. Thus, the concept of reflective learning where learning provides an opportunity for learners to change the pressure points in religious learning from "having religion" to "being religious" and "being humane." This fact implies that teaching religion is essential. Still, how to explore and understand more substantive religious values are more critical, so that one day they can become more spiritual and humanists. 


\section{REFERENCES}

Achmadi. Islam Sebagai Paradigma Ilmu Pendidikan. Yogyakarta: Aditya Media, 1992.

Annova, F, and S Fitriani. 'Applying the Concept of Islam Rahmatan Lil'alamin Through Arabic Learning to Student in STIT Syekh Burhanuddin

Pariaman Sumatera Barat'. KnE Social Sciences 3, no. 15 (31 March 2019): 127. https://doi.org/10.18502/kss.v3i15.4360.

Apriani, Eka, Irwan Fathurrochman, and Hendra Harmi. 'The Role of Islam

Rahmat Lil 'Alamin as the Solution For Exclusive Life in Indonesia'. AJIS: Academic Journal of Islamic Studies 3, no. 2 (30 December 2018): 192-206. https://doi.org/10.29240/ajis.v3i2.599.

Bone, Amra. 'Knowledge: The Qur'anic Discourse Concerning Reason and Revelation and Its Impact', n.d., 309.

Bornstein, Jaqueline L. 'Religion And Art As Peacebuilding Tools: A Case Study Of The Education Of Arts Appreciation Program, Solo, Indonesia', n.d., 210.

Burke, Joseph F. 'Mature Religious Behavior: A Psychological Perspective and Its Implications'. Journal of Religion and Health 17, no. 3 (1978): 177-83.

Chaer, Moh. Toriqul. 'Religious Pluralism: Between Syncretism And Tantularism'. Al-Albab 4, no. 1 (1 June 2015). https://doi. org/10.24260/alalbab.v4i1.279.

Challinor, Jane, Victoria I Marín, and Gemma Tur. 'The Development of the Reflective Practitioner through Digital Storytelling', n.d., 18.

Daradjat, Zakiah. Ilmu Jiwa Agama. Jakarta: PT. Bulan Bintang, 1996.

Davies, Douglas J. Religion and the Individual: Belief, Practice, and Identity.

Basel: MDPI AG, 2017. http://www.mdpi.com/books/pdfview/ book/337.

'Defining Human Development | Lifespan Development'. Accessed 16 March 2021. https://courses.lumenlearning.com/wmlifespandevelopment/chapter/defining-human-development/.

'Education - Aims and Purposes of Muslim Education | Britannica'. Accessed 16 March 2021. https://www.britannica.com/topic/education/ Aims-and-purposes-of-Muslim-education.

Hadi, Samsul, and Moh Toriqul Chaer. 'Character Education And The Strategy Of Building An Independent Learners'. EDUCATIO : 
Journal of Education 2, no. 2 (30 November 2017): 163-74. https:// doi.org/10.29138/educatio.v2i2.12.

Hasan, Fuad. Pendidikan Adalah Pembudayaan. In Tonny D. Widiastono (Ed), Pendidikan Manusia Indonesia (p. 52. Jakarta, 2004.

Hidayat, Nur. 'Peran Dan Tantangan Pendidikan Agama Islam Di Era Global'. EL TARBAWI 8, no. 2 (2015): 131-45. https://doi.org/10.20885/ tarbawi.vol8.iss2.art2.

'Islam Is a Religion of Peace - Foreign Policy'. Accessed 16 March 2021. https://foreignpolicy.com/2015/11/09/islam-is-a-religion-of-peacemanal-omar-debate-islamic-state/.

Jalaluddin. Psikologi Agama: Memahami Perilaku Dengan Mengaplikasikan Prinsip-Prinsip Psikologi. Jakarta: PT. Raja Grafindo Persada, 2015.

M. Suud, Fitriah, Abdul Gaffar, Kana Safrina Rouzi, and Moh. Toriqul Chaer. 'The Role of Islamic Counselling in Pandemic COVID 19: A Conceptual Study for Developing Positive Emotion of Parents and Children'. KONSELING RELIGI Jurnal Bimbingan Konseling Islam 11, no. 1 (29 June 2020): 18. https://doi.org/10.21043/ kr.v11i1.7705.

Masruhah, Ummahatul, Ely Mei Triyani, Aulia Sabrina, Rahmawati Prihastuty, S Psi, and M Si. 'Religious Tolerance to Adherents of Islam and Hinduism in Kongkong Village', n.d., 345.

Md sham, Fariza. 'Islamic Psychotherapy Approach In Managing Adolescent Hysteria In Malaysia'. Journal of Psychological Abnormalities in Children 04 (1 January 2015). https://doi.org/10.4172/23299525.1000142.

Moleong, Lexy J. Metode Kualitatif(Edisi Revisi). Bandung: PT. Rosda Karya, 2019.

Muhammad Iqbal, Abu. Pemikiran Pendidikan Islam: Gagasan-Gagasan Besar Para Ilmuwan Muslim. Yogyakarta: Pustaka Pelajar, 2015.

Munir Mulkhan, Abdul. Kesalehan Multikultur. Jakarta: PSAP Muhammadiyah, 2005.

Musnawar, Tohari. Etika Pembangunan Dalam Pemikiran Islam Di Indonesia (M. Husin, Ed.). Jakarta: Rajawali, 1986.

Nata, Abudin. Pendidikan Dalam Perspektif Al-Qur'an. Jakarta: Prena Media, 2016.

Rahman, Fazlur. 'Islam \& Modernity: Transformation of an Intellectual Tradition', 1982. https://core.ac.uk/display/296602457. 
Rouzi, Kana Safrina, Nikmah Afifah, Ciptro Hendrianto, and Desmita Desmita. 'Establishing an Islamic Learning Habituation Through the Prophets' Parenting Styles in the New Normal Era'. International Journal of Islamic Educational Psychology 1, no. 2 (19 December 2020): 101-11. https://doi.org/10.18196/ijiep.v1i2.9638.

Saeed, Abdullah. Interpreting the Qur'an: Towards a Contemporary Approach, 2005. https://doi.org/10.4324/9780203016770.

Sari, Nurlaela. 'The Importance Of Teaching Moral Values To The Students'. Journal of English and Education, 2013, 9.

Suliswiyadi, Suliswiyadi. 'Hierarki Ranah Pembelajaran Afektif Pendidikan Agama Islam Dalam Perspektif Taksonomi Qur'ani'. Jurnal Tarbiyatuna, 2020. https://doi.org/10.31603/tarbiyatuna. v11i1.3451.

'Hierarki Ranah Pembelajaran Afektif Pendidikan Agama Islam Dalam Perspektif Taksonomi Qur'ani'. Jurnal Tarbiyatuna 11, no. 1 (1 June 2020): 61-76. https://doi.org/10.31603/tarbiyatuna. v11i1.3451.

Sumantri, Rifki Ahda. 'Hermeneutika Al-Qur'an Fazlur Rahman Metode Tafsir Double Movement'. KOMUNIKA: Jurnal Dakwah dan Komunikasi 7, no. 1 (2013). https://doi.org/10.24090/komunika. v7i1.364.

'Hermeneutika Al-Qur'an Fazlur Rahman Metode Tafsir Double Movement'. Komunika 7, no. 1 (2013). https://doi.org/10.24090/ KOM.V7I1.2013.PP\%P.

Suradi, Ahmad. 'The Challenges of Education Based on Multicultural in National Local Culture Conservation in Globalization Era'. Cendekia: Jurnal Kependidikan Dan Kemasyarakatan 16, no. 1 (30 July 2018): 103. https://doi.org/10.21154/cendekia.v16i1.1156.

Theria Washim, Alef. Harmoni Kehidupan Beragama: Problem, Praktik Dan Pendidikan (Alef Theria Wasim Dkk (Ed). Yogyakarta: Proceeding Konferensi Regional International Association for the History of Religions., 2005.

Widigdo, Mohammad Syifa Amin. 'SUHRAWARDI'S ONTOLOGY: FROM "ESSENCE-EXISTENCE”TO “LIGHT": (A Suhrawardian Reply to Sadrian Critiques)'. Kanz Philosophia A Journal for Islamic Philosophy and Mysticism 4, no. 2 (1 December 2014): 117-26. 